\title{
Artikel
}

\section{Zes jaar later: met z'n allen verstrikt geraakt in het stelsel?!}

\author{
Actuele ontwikkelingen op het gebied van de Jeugdwet en jeugdbescherming
}

\section{Mr. E. Lam en mr. I.J.M. Schepens*}

Inmiddels zesenhalf jaar geleden, op 1 januari 2015, traden twee belangrijke wetswijzigingen op het gebied van de jeugdbescherming en de jeugdzorg ${ }^{1}$ in werking. De Jeugdwet beoogde een vereenvoudiging van het jeugdstelsel, door onder meer de verantwoordelijkheid voor de jeugdzorg bij gemeenten te beleggen en de eigen kracht van gezinnen en de sociale omgeving als uitgangspunt te nemen. De herziening van de kinderbeschermingsmaatregelen in het Burgerlijk Wetboek beoogde het belang en het recht van de minderjarige op een gezonde en evenwichtige ontwikkeling en groei naar zelfstandigheid centraal te stellen en te waarborgen.

Over beide wetswijzigingen schreven wij eerder een tweetal overzichtsartikelen in de voorganger van dit tijdschrift. ${ }^{2}$ Daarin hebben we stilgestaan bij de rechtspositie van de jeugdige en ouder in de Jeugdwet en zijn diverse vragen opgeworpen over de wijze waarop een antal belangrijke veranderingen zouden uitwerken in

Mr. E. Lam is werkzaam bij \&jeugd. \&jeugd richt zich op juridische ondersteuning van organisaties en (jeugd)professionals. Zij maakt deel uit van de redactie van dit tijdschrift. Mr. I.J.M. Schepens is werkzaam bij \&jeugd. \&jeugd richt zich op juridische ondersteuning van organisaties en (jeugd)professionals. Zij maakt deel uit van de redactie van dit tijdschrift.

1. In de Jeugdwet wordt gesproken over 'jeugdhulp en jeugdbescherming en jeugdreclassering' in plaats van jeugdzorg. Wij kiezen in dit artikel voor de term 'jeugdzorg' als verzamelterm voor alle vormen van vrijwillige en gedwongen hulpverlening.

2. Overzicht wijzigingen Herziening kinderbeschermingsmaatregelen, Tijdschrift Jeugdrecht in Praktijk, SDU, december 2014, E. Lam \& I.J.M Schepens; De stand van zaken twee later. Actuele ontwikkelingen op het gebied van de jeugdbescherming en de Jeugdwet, Tijdschrift Jeugdrecht in Praktijk, SDU, nummer 2, mei 2017. de praktijk. In onderhavig artikel borduren wij voort op deze artikelen en geven we een beeld van de bevindingen tot nu toe.

In het eerste deel gaan we in op actuele ontwikkelingen stelselbreed. Vervolgens staan we stil bij de praktijk van de kinderbeschermingsmaatregelen. Achtereenvolgens komen aan de orde de evaluatie herziening kinderbeschermingsmaatregelen, het aantal kinderbeschermingsmaatregelen, de krapte bij de Gecertificeerde Instellingen (hierna: GI): wachtlijsten en de rechtspraak, corona en de invloed op jeugdbescherming, Perspectiefbesluit, Machtiging uithuisplaatsing en reikwijdte, Vaststelling omgangsregeling en Ineffectieve OTS.

In het laatste deel van het artikel staan de bevindingen betreffende de Jeugdwet centraal. Daarbij besteden we onder meer aandacht aan de zogenaamde 'drangtrajecten', het woonplaatsbeginsel, de informatieplicht jegens de gezinsvoogd en het klacht- en tuchtrecht. We sluiten af met een conclusie.

Opmerking behoeft dat wij met dit artikel vooral beogen een overzicht te geven van ontwikkelingen en knelpunten. Deze zijn talrijk. Reden waarom wij keuzes hebben moeten maken welke onderwerpen en ontwikkelingen wij aan bod willen laten komen. De bedoeling van het artikel is niet zozeer om een juridische analyse te maken van alle ontwikkelingen en knelpunten in de jeugdhulp en jeugdbescherming, maar vooral om een overall beeld te schetsen: een beeld dat duidelijk maakt hoe complex de ondersteuning aan kinderen en gezinnen is georganiseerd waarbij het recht op bescherming van de kinderen door de overheid ernstig onder druk staat. 


\section{Actuele ontwikkelingen stelselbreed}

Eerst nog even terug naar de knelpunten die de Jeugdwet beoogde op te lossen:

- een te grote druk op gespecialiseerde zorg, waarbij onvoldoende gebruik werd gemaakt van preventieve en lichte ondersteuning en van de kracht van de jeugdige zelf en zijn sociale omgeving;

- tekortschietende samenwerking rond kinderen en gezinnen, als gevolg van de betrokkenheid van verschillende bestuurslagen en verschillende wettelijke systemen;

- afwijkend gedrag wordt onnodig gemedicaliseerd.

- lange wachtlijsten werden geconstateerd en de indicatiestelling kostte veel tijd, energie en geld. Dat was een langdurig en bureaucratisch proces;

- daarnaast werd aandacht gevraagd voor de bijzondere positie van kwetsbare gezinnen.

Geconcludeerd werd dat de versnippering van de jeugdhulp (toegang tot de jeugdhulp en provinciaal gefinancierde jeugd- en opvoedhulp, zorg voor jeugd met een licht verstandelijke beperking, jeugd-ggz, jeugdbescherming en jeugdreclassering) over verschillende wettelijke en bestuurlijke systemen veel problemen veroorzaakte. Stapsgewijs is gewerkt aan het vormgeven van een meer integraal stelsel, uitmondend in de inwerkingtreding van de Jeugdwet. De Jeugdwet heeft als doelstellingen: gebruikmaken van de eigen kracht van jongeren, ouders en hun sociale netwerk - demedicaliseren - eerder (jeugd)hulp bieden op maat voor kwetsbare kinderen, samenhangende hulp voor gezinnen bieden: één gezin krijgt één plan met één regisseur. De herziening van de kinderbeschermingsmaatregelen in het Burgerlijk Wetboek beoogde tegelijkertijd het belang en het recht van de minderjarige op een gezonde en evenwichtige ontwikkeling en groei naar zelfstandigheid centraal te stellen en te waarborgen.

Als we kijken naar de actuele situatie, dan buitelen berichten over financiële tekorten, wachtlijsten, personeelstekorten, bureaucratie, niet altijd beschikbaar hulp voor de meest kwetsbare kinderen, onvoldoende samenwerking, een niet goed functionerende keten wijkteamVeilig Thuis-Raad voor de Kinderbescherming-kinderrechter-GI over elkaar heen. En daarbij heeft het coronatijdperk nog voor extra complexiteit gezorgd en voor zorgen over het welzijn van kinderen en met name van jongeren. ${ }^{3}$ Natuurlijk worden er ook kinderen en gezinnen wel (goed) geholpen, maar het overheersende gevoel is dat de knelpunten de boventoon voeren. Hierna staan we kort stil bij de Eerste Evaluatie van de Jeugdwet, brieven aan de Tweede Kamer over de problemen in de jeugdhulp en jeugdbescherming, een toekomstscenario

3. Editorial: 'Covid-19 en het familie- en jeugdrecht', FJR 2020/28: de huidige Corona-crisis heeft grote gevolgen voor kinderen en de uitoefening en bescherming van hun rechten, wereldwijd. voor kind- en jeugdbescherming en een opsomming van diverse onderzoeken en programma's.

\section{Rapport Eerste evaluatie Jeugdwet}

In januari 2018 verscheen de 'Eerste evaluatie Jeugdwet: $\mathrm{Na}$ de transitie nu de transformatie'. ${ }^{4}$ Hiermee voldeed de regering aan het bepaalde in artikel 12.2 Jeugdwet, te weten om binnen drie jaar na inwerkingtreding van de Jeugdwet verslag uit te brengen over de doeltreffendheid en effecten van de wet in de praktijk. In een viertal deelstudies is de stand zaken onderzocht: Cliënten, Gemeenten, Zorglandschap en Veiligheid en Juridisch. Samengevat laat deze evaluatie zien dat de veranderingen sinds de invoering van de Jeugdwet vooral te kenmerken zijn als transitie. De gewenste transformatie moet nog grotendeels vorm krijgen. Uit de juridische analyse komt naar voren dat de rechtsbescherming bij jeugdhulp voor cliënten nog tekortschiet. Verschillende rechtswaarborgen voor betrokkenen bij jeugdhulp, zoals betrokken worden bij beslissingen over jeugdhulp, het krijgen van een verleningsbesluit voor jeugdhulp en het instellen van bezwaar en beroep tegen een beslissing over het al dan niet verlenen van jeugdhulp worden in de praktijk nog niet uitgevoerd zoals ze zijn bedoeld. Ook wordt geconstateerd dat de uitvoering van 'drang'trajecten in het schemergebied tussen vrijwilligheid en dwang (jeugdbescherming) door de jeugdbeschermingsorganisaties leidt tot rolonduidelijkheid en onwenselijk is. Ook is aandacht nodig voor het feit dat de toepassing van vrijheidsbeperkende maatregelen voor jeugdigen in een residentiële, niet-gesloten accommodatie niet is toegestaan. Voor vrijheidsbeperkingen bij gesloten jeugdhulp en privacyregels voor gegevensuitwisseling geldt dat een herbezinning op de huidige regelingen wenselijk is. Verder wordt opgemerkt dat er een spanning zit bij de inzet van gedwongen hulp als het gaat om verantwoordelijkheid van de Rijksoverheid (als verantwoordelijke voor het gehele jeugdstelsel) in relatie tot de verantwoordelijkheid van de gemeente.

$\mathrm{Er}$ is een 21-tal aanbevelingen gedaan om de transformatie verder vorm te geven.

Zorg voor de Jeugd

Op 16 april 2018 is naar aanleiding van de evaluatie aan de Tweede Kamer het programma 'Zorg voor de Jeugd' angeboden, een programma van het Ministerie van Volksgezondheid, Welzijn en Sport, Ministerie van Justitie en Veiligheid in partnerschap met Vereniging van Nederlandse gemeenten (VNG), Branches Gespecialiseerde Zorg voor Jeugd (BGZJ) en Landelijke Cliëntenorganisaties. Het gezamenlijke hoofddoel is de jeugdhulp, jeugdbescherming en jeugdreclassering merkbaar en meetbaar steeds beter te maken voor kinderen, jongeren en gezinnen, zodat ze op tijd passende hulp ontvangen. Het programma richt zich op het beter 
ondersteunen van kinderen, jongeren en gezinnen tijdens de levensloop van het kind (thuis, uitwonend, op school en bij 18 jaar) én het investeren in het vakmanschap van jeugdprofessionals. Hierin zijn de volgende zes concrete doelen/actielijnen geformuleerd:

1. betere toegang tot jeugdhulp voor kinderen en gezinnen;

2. meer kinderen zo thuis mogelijk laten opgroeien;

3. alle kinderen de kans bieden zich optimaal te ontwikkelen;

4. kwetsbare jongeren beter op weg helpen zelfstandig te worden;

5. jeugdigen beter beschermen als hun ontwikkeling gevaar loopt;

6. investeren in vakmanschap van jeugdprofessionals.

Binnen elke actielijn zijn er verschillende subdoelen en thema's geformuleerd. ${ }^{5}$ Het programma heeft al tot diverse mooie ontwikkelingen en verbeteringen geleid van de hulp en ondersteuning aan jeugdigen en gezinnen, zoals een afspraak over verlenging van pleegzorg tot de leeftijd van 21 jaar en het terugdringen van gedwongen afzonderen van jongeren binnen de gesloten jeugdhulp. Zie voor de ontwikkelingen binnen de jeugdbescherming ook het artikel 'Pilots in de jeugdbescherming, een motor voor reflectie, vragen en innovatie' waarin Helmich stilstaat bij innovatie, de totstandkoming hiervan en hoe deze innovatie leidt tot overwegingen voor een volgende stap richting de toekomst van jeugd- en gezinsbescherming. ${ }^{6}$

Voortgang ontwikkelingen

In diverse brieven aan de Tweede Kamer informeren de ministers De Jonge en Dekker de Kamer over de voortgang van de ontwikkelingen binnen de jeugdzorg. Zo wordt in de brief 'Naar een betere organisatie van jeugdhulp, jeugdbescherming en jeugdreclassering' van 7 november 2019, gesteld dat de uitvoering van de jeugdbescherming onder grote druk staat en worden diverse acties geformuleerd om tot verbeteringen te komen, zoals het versterken van jeugdregio's door duidelijkheid te scheppen over de inrichting en taken van jeugdregio's en wordt benoemd dat jeugdhulpaanbieders en gecertificeerde instellingen een fair tarief dienen te ontvangen voor hun diensten. Tevens wordt bepleit dat meer eenheid nodig is in de toegang tot jeugdhulp, zodat voor gezinnen en professionals helder is wat van de gemeentelijke toegang/lokale teams mag worden verwacht. Als aanpak van het tekort aan jeugdprofessionals, met name jeugdbeschermers, wordt een arbeidsmarkttafel jeugdsector ingesteld. Bij die brief is gevoegd het rapport 'Kwetsbare kinderen onvoldoende beschermd' van de Inspecties Inspectie voor de Gezondheidszorg en Jeugd en de Inspectie Justitie en Veiligheid van november 2019 waarin stevige conclusies worden getrokken over de overheid. Geconcludeerd wordt dat de overheid onvoldoende haar verantwoordelijkheid neemt om kinderen te beschermen die ernstig in hun ontwikkeling

5. www.voordejeugd.nl.

6. TVJr 2020/4 worden bedreigd. Het gaat hier om kinderen bij wie sprake is van mishandeling of verwaarlozing. Deze kwetsbare kinderen moeten zonder vertraging de hulp krijgen die ze nodig hebben. Daarom moeten direct stappen worden gezet die ertoe leiden dat de jeugdbescherming voor deze kinderen beter functioneert, aldus de Inspecties. ${ }^{7}$

In de brief 'Perspectief voor de jeugd' van 20 maart 2020, informeren De Jonge en Dekker de Tweede Kamer over voorstellen om de organisatie van de jeugdzorg te verbeteren. Benoemd wordt dat regionale samenwerking nodig is om de kwaliteit en de continuiteit van de zorg aan kinderen met complexe problemen en specialistische en levensbrede vraagstukken beter te borgen. Verder wordt ingezet op het versterken van opdrachtnemer- en werkgeverschap van jeugdhulpaanbieders en goed bestuur, kaders voor reële tarieven en zorgvuldigheidseisen bij de inkoop, een effectievere bescherming van jeugd en gezin, het versterken van toezicht op zorg voor de jeugd en een lerende praktijk in de regio's.

In de voortgangsrapportage van de Inspectie Gezondheidszorg en Jeugd 'Kwetsbare kinderen onvoldoende beschermd' van 15 oktober 2020 concludeert de inspectie dat er onvoldoende is gebeurd voor de kinderen die nu een kinderbeschermings- of jeugdreclasseringsmaatregel hebben en nog geen hulp krijgen. Een actiegerichte aanpak is nodig om deze groep kinderen tijdig passende hulp te kunnen bieden. In een voortgangsbrief van 16 november 2020 informeren de Ministers de Tweede Kamer over de actuele ontwikkelingen. Door de VNG, BGZJ en het Rijk zijn afspraken gemaakt over een doorbraakaanpak om voor kinderen met een kinderbeschermingsmaatregel tijdig jeugdbescherming en passende jeugdhulp te organiseren. ${ }^{8}$

\section{Wetsvoorstellen wijzigingen Jeugdwet}

Naar aanleiding van onder andere de hiervoor genoemde knelpunten en ontwikkelingen binnen het Programma Zorg voor de Jeugd is een aantal wetsvoorstellen die tot wijziging van de Jeugdwet leiden in voorbereiding:

- Wetsvoorstel 'Verbetering beschikbaarheid zorg voor jeugdigen, een wetsvoorstel gericht op de bevordering van beschikbaarheid van zorg, regionale samenwerking, toegang, governance en toezicht'; 9

- (Concept)wetsvoorstel 'Rechtspositie gesloten jeugdhulp', een lang verwacht en nodig geacht ${ }^{10}$ ) wetsvoorstel dat voorziet in een integrale regeling voor de (interne) rechtpositie van jeugdigen die op grond van een rechterlijke beslissing in een gesloten

7. https://www.inspectie-jenv.nl/actueel/nieuws/2019/11/08/inspectieskwetsbare-kinderen-onvoldoende-beschermd.

8. https://www.rijksoverheid.nl/documenten/kamerstukken/2020/11/16/ kamerbrief-over-voortgangsbrief-jeugd.

9. www.huiselijkgeweld.nl/actueel/nieuws/2021/03/08/wetsvoorstelverbetering-beschikbaarheid-zorg-voor-jeugdigen.

10. Zie ook A.C. Quick-Schuijt “Een reactie op het artikel "Klachtrecht voor jongeren die van hun vrijheid zijn beroofd", FJR 2008, 3', FJR 2008/7 en J. uit Beijerse, 'Jeugdigen in justitiële jeugdinrichtingen en jeugdzorgplus: gescheiden, maar ook een andere rechtspositie?', FJR 2016/9. 
instelling verblijven: een instelling voor gesloten jeugdhulp of een justitiële jeugdinrichting; ${ }^{11}$

- Wetsvoorstel 'Wijziging van de Jeugdwet en enkele andere wetten in verband met de verlenging van de duur van pleegzorg en het vervallen van de verleningsbeschikking bij machtigingen tot uithuisplaatsing en gesloten jeugdhulp'; 12

- Wetsvoorstel 'Wijziging van de Jeugdwet en de Wet maatschappelijke ondersteuning 2015 teneinde de uitvoeringslasten bij het aanbesteden van diensten als bedoeld in die wetten te verlichten, alsmede grondslagen op te nemen voor het stellen van regels die bij de inkoop of subsidiëring van die diensten in acht worden genomen (Wet maatschappelijk verantwoord inkopen Jeugdwet en Wmo 2015)'. ${ }^{13}$

Zie voor een volledig overzicht de bijlage met wetsvoorstellen bij de voorgenoemde brief van 16 november 2020 .

Toekomstscenario kind- en gezinsbescherming De Tweede Kamer heeft op verschillende momenten aandacht gevraagd voor de noodzaak van verbetering en vereenvoudiging van de jeugdbeschermingsketen. Als knelpunten worden genoemd dat er veel organisaties zijn die werken met een gezin die onvoldoende op elkaar aansluiten en aparte schakels vormen, dat de jeugdbeschermingsketen complex is georganiseerd en dat het estafettemodel ervoor zorgt dat kinderen en gezinnen vaak lang moeten wachten op bescherming en hulp. Ook de achterliggende problematiek binnen het gezin krijgt te weinig aandacht. Als de problemen van een kind voortkomen uit of samenhangen met problemen van de ouders, dan zijn het de ouders die aan de slag moeten. De inzet van een kinderbeschermingsmaatregel (alleen) is dan niet altijd passend en effectief. ${ }^{14}$ In de zomer van 2020 is een kwartiermaker aangesteld die in gezamenlijk opdrachtgeverschap van het Rijk (JenV en VWS) en de VNG aan de slag is gegaan om samen met uitvoeringspartijen, departementen, gemeenten, cliënten, burgers, toezichthouders, wetenschap en andere 'kennisdragers' te komen tot een gedragen scenario en beoordelingskader.

Op 30 maart jl. is het toekomstscenario kind- en gezinsbescherming naar de Tweede Kamer gestuurd en is het scenario ter consultatie aangeboden. ${ }^{15}$ Het toekomstscenario is ontwikkeld in gezamenlijk opdrachtgeverschap van het Rijk (JenV en VWS) en de VNG en betekent een grote innovatie en verandering in de jeugdbeschermingsketen. Op termijn moet het toekomstscenario een structurele oplossing bieden voor de knelpunten in de

11. Kamerstukken II, 2020/21, 35833.

12. Kamerstukken II, 2020/21, 35833.

13. Kamerstukken II, 2020/21, 35816.

14. Zie ook motie van het lid Van Toorenburg c.s. over afdwingbare ondertoezichtstelling van opvoeders is de regering verzocht om in onderliggend scenario expliciet de interventiemogelijkheden binnen de civielrechtelijke kinderbescherming uit te breiden met afdwingbare ondertoezichtstelling van opvoeders, teneinde hen te bewegen hulp te accepteren, Kamerstukken II, 2020/21, 35570 VI, nr. 48.

15. https://www.internetconsultatie.nl/toekomstscenario. jeugdbescherming.. Het scenario is gestoeld op vier pijlers: gezinsgericht - rechtsbeschermend en transparant - eenvoudig - lerend. Voorgesteld wordt om voor het gezin een vast gezicht te hebben en als er zorgen zijn bij het lokaal team over de veiligheid in het gezin of de ontwikkeling van kinderen, de expertise van een veiligheidsteam toe te voegen. In dit veiligheidsteam worden taken van Veilig Thuis, de Raad voor de Kinderbescherming ( RvdK) en Gecertificeerde Instelling (GI) samengebracht. Het toekomstscenario bevat ook een stappenplan: werken aan die toekomst vraagt om een toegewijde aanpak van een meervoudig vraagstuk, verdere verdieping, uitwerking, ontwikkeling en beproeving. Dit proces duurt naar schatting vijf tot tien jaar en het valt grofweg in vier fasen uiteen:

- fase 0: Voorbereiding en start.

- fase 1: Beproeven en ontwikkelen.

- fase 2: Evaluatie en besluitvorming.

- fase 3: Landelijk implementeren en verankeren, aldus het scenario.

Het is afwachten wat de reacties op het scenario zijn en hoe het uiteindelijke scenario eruit zal komen te zien. Duidelijk is wel dat de huidige inrichting van de jeugdbescherming van lokale toegang - Veilig Thuis - RvdK - kinderrechter - GI onvoldoende functioneert als het gaat om de bescherming van de meest kwetsbare kinderen en gezinnen en dat de urgentie hoog is om aanpassingen te gaan doen in het stelsel.

Analyses knelpunten en oplossingsrichtingen Hiervoor kwam al aan de orde dat uit de Eerste Evaluatie Jeugdwet naar voren komt dat de transitie nog in volle gang is en verschillende berichten over de problemen in het jeugdstelsel elkaar snel opvolgen. Dat geldt ook voor het aantal onderzoeken. In diverse (andere) onderzoeken en rapporten wordt een nadere analyse gegeven van de problemen van het stelsel en worden mogelijke oplossingsrichtingen gegeven om de gesignaleerde knelpunten aan te pakken.

Wij noemen - niet uitputtend -:

- Feugdzorg: van systemen naar mensen, SER, 21 mei 2021;

- Ontwikkelen over de grenzen heen. Onderzoek naar de mettelijke knelpunten, Andersson Elffers Felix (AEF), april 2021;

- Adviesrapport, Expertteam ouderverstoting/complexe omgangsproblematiek, januari 2021;

- Samen verder, Kinderen en gezinnen met complexe problemen samen verder helpen, IJZ, Kinderombudsman, NOM, NZA, RVS, april 2021;

- Stelsel in groei. Een onderzoek naar financiële tekorten in de jeugdzorg, AEF, 15 december 2020;

- Kan huiselijk gemeld en kindermishandeling echt stoppen? Kmestie van lange adem, Verweij-Jonker, 12 november 2020;

- Sociaal Domein op koers, Sociaal en Cultureel Planbureau 2020;

- Samenwerken aan een Veilig Thuis, AEF, november 2020; 
- Feugdbescherming, inzicht uit Duitsland, Denemarken en Zweden, Nederlands Jeugdinstituut NJi 2020;16

- Kan huiselijk gemeld en kindermishandeling echt stoppen? Kmestie van lange adem, Verweij-Jonker, 12 november 2020;

- Samenmerken aan veiligheid: de merkmijze $M D A++$ Friesland, Vermeij-Jonker, 2020;

- Eindrapport Uitvoering Meerjaren agenda zorg- en veiligheidshuizen 2017-2020;

- Zorg voor de toekomst. Over de toekomstbestendigheid van de zorg, Sociaal Economische Raad (SER), 2020;

- De kracht van wijd reiken. Advies om de transformatie van de jeugdhulp te laten slagen, VNG expertiseteam, maart 2020;

- Het groeiend jeugdzorggebruik. Duiding en aanpak, NJi, 2019;

- Onderzoek afbakening jeugdhulp zonder verblijf, JB Lorenz, mei 2020;

- Rapporten Brede maatschappelijke herovermegingen, ambtelijke werkgroepen Ministeries, 22 april 2020;

- De duur van jeugdhulptrajecten, I\&O Research, april 2020;

- Veldscan expertisecentra specialistische jeugdhulp, AEF, april 2020;

- Vraag en aanbod jeugdzorg plus: factoren die van invloed zijn op de ontmikkeling van jeugdzorgregio's, DSP, december 2019;

- Intensieve vrijmillige hulp. Heldere grenzen aan drang in de jeugdzorg, Raad voor Strafrechttoepassing en jeugdbescherming (RSJ) en de Raad voor Volksgezondheid en Samenleving (RVS), 25 november 2019;

- Basisfuncties voor lokale teams in kaart, KPMG, november 2019;

- Kmaliteitskader Werken aan Veiligheid voor lokale teams, VNG november 2019;

- ZonMw programmalijn 'Gemeld hoort nergens thuis'. Aanpak huiselijke gemeld en kindermishandeling in het lokaal veld: randvoormaarden voor regie, samenmerking en afstemming op operationeel niveau, $\mathrm{NJ}$;

- ZonMm programmalijn 'mat merkt voor de jeugd'. Krachten bundelen bij wijkgericht werken voor jeugd en gezin, $\mathrm{NJi}$;

- Fustitieel interventiepalet kindermishandeling, Breuer \& Intraval, oktober 2019;

- Quickscan RvdK: breed perspectief op oorzaken en verbeterrichtingen machtlijsten, KPMG 16 augustus 2019;

- Paradigma's in het sociaal domein, Argumenten fabriek, maart 2018.

16. Deze quickscan is een uitwerking van de motie Van der Staaij/Bergkamp (Kamerstukken // 2019/20, 35300 XVI/nr. 116), waarin verzocht werd het oog op de door de inspectie wenselijk geachte verkorting van de keten van jeugdbescherming ook te bezien hoe in andere Europese landen het feitenonderzoek en de rechterlijke toets zijn vormgegeven en de Kamer gelijktijdig met de resultaten van de pilots te informeren over de lessen hieruit voor het Nederlandse stelsel.
Daarnaast zijn er naast het al benoemde programma Zorg voor de Jeugd nog andere programma's die gericht zijn op het aanpakken en verbeteren van bepaalde problematiek zoals:

- Programma Sociaal Domein;

- Programma Maatwerk Multiprobleemhuishoudens;

- Scheiden zonder schade;

- Geweld Hoort Nergens Thuis;

- Actieprogramma Kansrijke Start;

- Actieprogramma Dak- en Thuisloze Jongeren 2019-2021;

- Integraal werken in de wijk;

- De Juiste Zorg op de Juiste plek;

- Verbetertraject Samenwerken aan een betere toegang.

Het aantal onderzoeken en programma's is talrijk. Het roept bij ons de vraag op of en, zo ja, hoe het mogelijk is hieruit de rode draad te halen? Wat zijn de gemeenschappelijke delers en tegenstellingen? En hoe kan op basis hiervan een positieve impuls aan de jeugdzorg worden gegeven?

\section{Kinderbeschermings- maatregelen}

Onder het kopje 'Actuele ontwikkelingen stelselbreed' hebben we stilgestaan bij de knelpunten die binnen het huidige stelsel worden ervaren. In deze paragraaf zullen we inzoomen op een aantal specifieke onderwerpen die betrekking hebben op de herziene kinderbeschermingsmaatregelen.

\section{Evaluatie Herziening}

kinderbeschermingsmaatregelen

Net als bij de Jeugdwet heeft er ook een tussenevaluatie van de Wet herziening kinderbeschermingsmaatregel plaatsgevonden. ${ }^{17}$ Geconcludeerd is onder meer dat de grond 'acceptatie van hulp' in de rechtsgrond van de ondertoezichtstelling (hierna: OTS) niet strikt wordt toegepast. Naast acceptatie in de zin van 'bereidheid hulp te aanvaarden' wordt onder acceptatie ook verstaan 'het in staat zijn de ernstige ontwikkelingsbedreiging van het kind weg te nemen'. ${ }^{18}$ Verder lijkt het doel van de wet, een duidelijke scheiding tussen vrijwillig en gedwongen kader met de nieuwe gronden 'acceptatie' en 'aanvaardbare termijn', niet bereikt te worden. Nader onderzoek naar de reikwijdte van drangtrajecten en de rechtswaarborgen in verhouding tot de rechtsgronden is gewenst. Geconstateerd wordt ook dat er een verschil bestaat tussen de intentie van de ketenpartners om het

17. Tussenevaluatie Wet Herziening Kinderbeschermingsmaatregelen, Verwey Jonker Instituut en UCERF, juli 2018.

18. In een uitspraak van 16 februari 2018 heeft de Hoge Raad het vereiste dat de noodzakelijke zorg 'niet of onvoldoende wordt geaccepteerd' uitgelegd als dat het onvermogen van een ouder om de noodzakelijke zorg daadwerkelijk te benutten, terwijl deze zich wel bereid heeft verklaard tot acceptatie, niet aan het uitspreken van een ondertoezichtstelling in de weg staat (ECLI:NL:HR:2018:218) 
kind te horen en het spreken met kinderen in de praktijk. Er zijn goede initiatieven, maar het spreken met kinderen behoeft zowel in frequentie als wat betreft de kwaliteit verbetering. Aan de gedachte van de wetgever dat gezag en feitelijke opvoeding zoveel mogelijk in één hand liggen en dus bij een gezagsbeëindiging de pleegouders met de voogdij worden belast, wordt nog niet volop uitvoering gegeven. Dat geldt ook voor de mogelijkheid dat de burgemeester of de GI toegang tot de rechter heeft in het geval zij het oneens zijn met het oordeel van de Raad voor de Kinderbescherming (hierna: RvdK) dat er geen gronden zijn voor OTS of een beëindiging van het ouderlijk gezag. ${ }^{19}$ Het is nu afwachten op de bevindingen van de (definitieve) evaluatie, die voor 2020 stond gepland en naar verwachting begin 2022 wordt afgerond.

\section{Aantal kinderbeschermingsmaatregelen}

Waar de Jeugdwet als uitgangspunt neemt dat ouders de eerst verantwoordelijken zijn voor de opvoeding en verzorging van hun kinderen en vergroting van de eigen kracht wordt beoogd, wordt bij de herziening van de kinderbeschermingsmaatregelen het belang voor de minderjarige, ${ }^{20}$ om zo snel mogelijk duidelijkheid te scheppen over zijn opvoedperspectief, vooropgesteld. In onze eerdere stand van zaken ${ }^{21}$ stelden we ons de vraag in hoeverre dit zou leiden tot minder verzoeken tot een OTS en of hiertoe alleen zou worden overgegaan als overduidelijk is dat ouders de verantwoordelijkheid voor de verzorging en opvoeding van de minderjarige niet aan kunnen en/of de benodigde zorg niet accepteren. Uit de toenmalige cijfers kwam naar voren dat het percentage OTS-maatregelen binnen het totaal van jeugdbeschermingsmaatregelen dalende was en de verhouding tussen de maatregelen OTS en voogdij veranderde. Deze tendens - waarin een stijging van aantal voogdijzaken ten opzichte van een daling van aantal ondertoezichtstellingen werd gezien - heeft zich volgens de huidige cijfers van het CBS de afgelopen jaren niet voortgezet.

Uit de laatstelijk door het CBS gepubliceerde cijfers over de jeugdbescherming en jeugdreclassering blijkt dat er op 31 december 202032.800 lopende jeugdbeschermingsmaatregelen waren. ${ }^{22}$ Twee derde daarvan was een vorm van OTS en een derde een voogdijmaatregel.

19. Het onderzoek is namens WODC uitgevoerd door Verwey-Jonker Instituut Utrecht Centre for European Research into Family Law (UCERF), zie https://repository.wodc.nl/handle/20.500.12832/2362

20. Als het over de kinderbeschermingsmaatregelen gaat wordt gesproken over minderjarige of kind, de begrippen zoals die worden gehanteerd in het Burgerlijk Wetboek en het IVRK. Als er gesproken wordt over 'jeugdige' duidt dit op de term die in Jeugdwet wordt gebruikt en die o.g.v. de begripsbepaling in art. 1.1 van de Jeugdwet ook betrekking heeft op personen ouder dan 18 jaar.

21. 'Overzicht wijzigingen Herziening kinderbeschermingsmaatregelen', Tijdschrift Jeugdrecht in Praktijk, SDU, december 2014, E. Lam \& I.J.M. Schepens, 'De stand van zaken twee later. Actuele ontwikkelingen op het gebied van de jeugdbescherming en de Jeugdwet', Tijdschrift Jeugdrecht in Praktijk, SDU, nummer 2, mei 2017.

22. Jeugdbescherming en jeugdreclassering 2020, CBS 2020.
Sinds 2016 stijgt het aantal jongeren met een OTS. In de periode $2015 \mathrm{t} / \mathrm{m} 2020$ ligt de instroom van jongeren in de jeugdbescherming tussen 9.425 (in 2015) en 11.450 (in 2019). Het aantal jongeren dat in 2020 is ingestroomd in de jeugdbescherming ligt met 10.310 lager dan in 2019.

Sinds 2017 ligt het aantal voogdijmaatregelen redelijk constant rond de 9.900. In de jaren daarvoor was een duidelijke stijging te zien; uit de cijfers van het CBS komt naar voren dat het aantal voogdijmaatregelen in de periode 2005 tot en met 2016 bijna verdubbeld is, maar sindsdien redelijk constant blijft.

Er werden in 2020 minder OTS-maatregelen gestart, maar ook minder beëindigd dan in voorgaande jaren. Daarnaast blijkt uit de cijfers dat de gemiddelde duur van ondertoezichtstellingen afnam en bij voogdijmaatregelen toenam. De meeste trajecten werden beëindigd vanwege het bereiken van de meerderjarigheid van de jongeren. Opvallend is te noemen dat in 2020 steeds minder ondertoezichtstellingen beëindigd werden vanwege een gezagsbeëindigende maatregel. Het aantal voogdijmaatregelen dat is beëindigd door herstel van het gezag, is daarentegen de afgelopen jaren gestegen.

Kortom, de herziening van de kinderbeschermingsmaatregelen lijkt op basis van deze cijfers vooralsnog weinig effect te hebben op aantal en aard van de maatregelen. Wij zijn benieuwd hoe deze cijfers over aantal en soort kinderbeschermingsmaatregelen worden geduid bij de eindevaluatie van de herziene kinderbeschermingsmaatregelen.

Krapte bij GI's: wachtlijsten en de rechtspraak Niet alleen de Inspectie Gezondheidszorg en Jeugd (IGJ) heeft haar zorgen geuit over de gebrekkige beschikbaarheid van hulp voor de kinderen met een kinderbeschermingsmaatregel. ${ }^{23}$ Ook vanuit de rechtspraak is in de loop van de afgelopen jaren de noodklok geluid om aandacht te vragen voor de krapte bij de GI's. De transitie heeft mede geleid tot hoge werkdruk en personeelstekorten bij de GI's, waardoor kinderbeschermingsmaatregelen niet (direct) kunnen worden opgepakt. De eerste noodkreten vanuit de rechtspraak kwamen in 2018 vanuit de rechtbank Rotterdam en in 2019 vanuit de rechtbank Zeeland West-Brabant. $^{24}$ Laatstgenoemde rechtbank vroeg aandacht voor de wachtlijstproblematiek door in de zomer van 2019 diverse uitspraken te doen en deze te publiceren. ${ }^{25}$

$\mathrm{Nu}$ de wachtlijstproblematiek nog steeds actueel is, zijn er diverse uitspraken te vinden waaruit duidelijk wordt op welke manieren de rechtspraak probeert invloed uit te oefenen. Manieren waarop rechters trachten om te gaan met de wachtlijstproblematiek, zijn het toewijzen

23. Rapport kwetsbare kinderen onvoldoende beschermd, 8 november 2019 en Voortgangsrapportage kwetsbare kinderen onvoldoende beschermd, 15 oktober 2020.

24. Rb. Rotterdam 17 december 2018, ECLI:NL:RBROT:2018:10563.

25. Rb. Zeeland-West-Brabant 2 juli 2019, ECLI:NL:RBZWB:2019:3252, Rb. Zeeland-West-Brabant 2 juli 2019, ECLI:NL:RBZWB:2019:3249, Rb. Zeeland-West-Brabant 17 juni 2019, ECLI:NL:RBZWB:2019:3091. 
van de (verlenging van de) ondertoezichtstelling voor kortere duur, ${ }^{26}$ het intrekken van de machtiging uithuisplaatsing, ${ }^{27}$ het afwijzen van het verzoek verlenging OTS en machtiging uithuisplaatsing ${ }^{28}$ of een combinatie van een kortere toewijzing en een opdracht aan de GI. ${ }^{29}$ Daarnaast zorgden actuele ontwikkelingen in de Zeeuwse jeugdzorg ten gevolge van onduidelijkheid over het voorbestaan van Intervence en het intrekken van het certificaat voor Briedis ervoor dat eind april 2021 de rechtbank Zeeland-West-Brabant opnieuw zorgen heeft geuit over de situatie. De kinderrechter houdt het verzoek van de Raad strekkende tot ondertoezichtstelling voor korte tijd aan, in afwachting van (onder meer) de beschikbaarheid van een GI. ${ }^{30}$

Opmerking verdient tevens dat de kinderrechters ook zorgen hebben over de lange wachtlijsten bij jeugdhulpaanbieders. Deze zorgen passen - aldus de kinderrechters - in het beeld dat andere organisaties zoals de Inspectie Gezondheidszorg en Jeugd, de Kinderombudsman, de Nationale Ombudsman, Nederlandse Zorgautoriteit en Raad voor Volksgezondheid \& Samenleving eerder schetsten. ${ }^{31}$ Hiermee wordt gedoeld op de notitie 'Samen verder' die door genoemde organisaties is gepubliceerd in april $2021 .{ }^{32}$

De wachtlijstproblematiek bij jeugdhulpaanbieders die leidt tot het niet kunnen plaatsen van kinderen komt onder meer naar voren in uitspraken van de rechtbank Rotterdam, ${ }^{33}$ van de rechtbank Midden Nederland ${ }^{34}$ en van de rechtbank Zeeland West-Brabant. ${ }^{35}$

Zoals eerder vermeld zijn inmiddels door de VNG, BGJZ en het Rijk afspraken gemaakt over een doorbraakaanpak om tijdig jeugdbescherming en passende jeugdhulp te organiseren. Gemeenten, jeugdhulpregio's en GI's hebben in dat kader de opdracht gekregen werkafspraken te maken zodat per kind jeugdbescherming en passende jeugdhulp wordt georganiseerd. Uit de voortgangsbrief jeugd van 17 juni 2021 komt naar voren dat de eerste resultaten van de aanpak zichtbaar zijn: 'de anpak is in alle regio's daadwerkelijk gestart, de samenwerking tussen de partijen is versterkt en (door)ontwikkeld en een aantal partijen heeft lessen getrokken en/of succesfactoren geidentificeerd die bijdragen aan het sneller oplossen van toekomstige casussen'. ${ }^{36}$ De

26. Rb. Zeeland-West-Brabant 17 juni 2019, ECLI:NL:RBZWB:2019:3090 en 3091, Rb. Zeeland-West-Brabant 2 juli 2019, ECLI:NL:RBZWB: 2019:3252.

27. Rb. Rotterdam 30 augustus 2019, ECLI:NL:RBROT:2019:7416.

28. Rb. Zeeland-West-Brabant 24 januari 2020, ECLI:NL:RBZWB:2020:708.

29. Rb. Zeeland-West-Brabant 2 oktober 2019, ECLI:NL:RBZWB: 2019:4616; Rb. Midden-Nederland 30 januari 2020, ECLI:NL:RBMNE: 2020:561.

30. Rb. Zeeland-West-Brabant 22 april 2021, ECLI:NL:RBZWB:2021:2342.

31. www.rechtspraak.nl/Organisatie-en-contact/Organisatie/Rechtbanken/ Rechtbank-Zeeland-West-Brabant/Nieuws/Paginas/Rechtbankzeeland-west-brabant-heeft-zorgen-over-situatie-jeugdzorgzeeland.aspx.

32. Samen verder, kinderen en gezinnen met complexe problemen samen verder helpen, Den Haag, april 2021.

33. Rb. Rotterdam 31 oktober 2019, ECLI:NL:RBROT:2019:9572.

34. Rb. Midden-Nederland 7 janauri 2021, ECLI:NL:RBMNE:2021:836.

35. Rb. Zeeland-West-Brabant 4 maart 2021, ECLI:NL:RBZWB:2021:1174.

36. Kamerstukken II, 2020/21, 31839, nr. 784. inspecties toetsen momenteel het effect van de doorbraakaanpak in de regio's en geven hierover in de zomer een oordeel.

Corona en de invloed op jeugdbescherming De uitbraak van COVID-19 heeft vanzelfsprekend ook invloed op de uitvoering van kinderbeschermingsmaatregelen en de rechtspraak hierover. De meest opvallende ontwikkelingen zijn in dit verband de invloed die COVID-19 had op:

a. De duur van maatregelen

Bij aanvang van de maatregelen rondom COVID-19 vonden er geen of nauwelijks fysieke zittingen plaats. Dit bracht de rechtbank Rotterdam ertoe om na een telefonische hoorzitting de verzochte ondertoezichtstelling (voor twaalf maanden) uit te spreken voor zeven maanden en voor het overige aan te houden. ${ }^{37}$ Een andere situatie waarin COVID-19 invloed had op de duur van de maatregel betreft de uitspraak van de rechtbank Midden-Nederland van 8 mei 2020. De rechtbank sprak een kortere verlenging van de machtiging uithuisplaatsing uit in verband met het versneld toewerken naar terugplaatsing bij de moeder. In verband met de coronamaatregelen zou een terugplaatsing te lang duren, met risico op verdere verwijdering van de ouders. ${ }^{38}$

b. Omgangs- en zorgregelingen

Het wekt geen verbazing dat COVID-19 in kinderbeschermingszaken veel invloed heeft op de (nakoming van) omgangs- en zorgregelingen, vooral in zaken waarin sprake is van begeleide omgang, situaties van uithuisplaatsingen en scheidingszaken. De kaders waar de GI's zich gedurende de coronamaatregelen in belangrijke mate op baseren bij het vormgeven van omgangs- en contactregelingen zijn de richtlijnen van het Nederlands Jeugdinstituut.

In de rechtspraak zijn diverse uitspraken terug te vinden waarin de invloed van COVID-19 op omgangs- en contactregelingen naar voren komt.

Zo liet de rechtbank Rotterdam een schriftelijke aanwijzing (in de vorm van een e-mail) in stand waarbij (begeleid) contact enkel werd toegestaan door middel van videoverbinding. ${ }^{39}$ De rechtbank onderschreef dat vanwege de veiligheidsrisico's voor alle betrokkenen het landelijke coronabeleid - dat geen (fysieke) begeleide omgang plaatsvindt - ook voor de GI geldt.

Ook in andere situaties waren rechters minder strikt en werd rekening gehouden met de omstandigheden. Zo werd door de rechtbank Noord-Nederland bij de totstandkoming en de inhoud van de schriftelijke aanwijzing rekening gehouden met de bijzondere omstandigheden door de uitbraak van het coronavirus ${ }^{40}$ en was de opschorting van de omgangsregeling door de GI volgens

37. Rb. Rotterdam 27 maart 2020, ECLI:NL:RBROT:2020:3213

38. Rb. Midden-Nederland 8 mei 2020, ECLI:NL:RBMNE:2020:1799.

39. Rb. Rotterdam 3 april 2020, ECLI:NL:RBROT:2020:3780.

40. Rb. Noord-Nederland 12 juni 2020, ECLI:NL:RBNNE:2020:2378. 
de rechtbank Amsterdam gerechtvaardigd in verband met de coronacrisis. ${ }^{41}$

Deze bijzondere omstandigheden konden niet in alle gevallen op begrip rekenen. Zo was de rechtbank Noord-Nederland van mening dat de eerder gemiste tijd bij de andere ouder moest worden gecompenseerd en leidde dit tot toewijzing van een vordering tot nakoming in kort geding. ${ }^{42}$ Belangrijke overweging hiervoor was dat de versoepeling van de maatregelen al eerder fysieke hervatting van de geldende zorgregeling toeliet. Anderzijds oordeelde het hof Arnhem-Leeuwarden in mei 2020 dat COVID-19 geen grond is voor een algehele schorsing van de uitvoerbaarheid. ${ }^{43}$ Het hof overweegt dat COVID-19 wellicht tot maatwerk noopt, in dit geval ten aanzien van een opbouwregeling voor omgang, maar geen grond oplevert voor algehele schorsing van de uitvoerbaarheid.

\section{Perspectiefbesluit}

Steeds vaker komen we - hoewel er al langere tijd mee wordt gewerkt - in de rechtspraak de term perspectiefbesluit, opvoedbesluit of opvoedbeslissing tegen. Dit is een niet-juridisch, maar eerder pedagogisch besluit waarin een oordeel wordt gegeven over het perspectief van een minderjarige in het kader van de ondertoezichtstelling. Dit vloeit voort uit de aanvaardbare termijn die is opgenomen in de kinderbeschermingswetgeving en de verplichting van de GI om bij een verlengingsverzoek van een ondertoezichtstelling en machtiging uithuisplaatsing na twee jaar het advies van de Raad bij het verzoek te voegen. Het 'perspectiefbesluit' beantwoordt de vraag: kan een kind definitief wel of niet terug naar huis? Het is feitelijk het belangrijkste moment bij een uithuisplaatsing in het gedwongen kader.

Een aantal uitspraken waarin het perspectiefbesluit een rol speelde, stippen we hier kort aan.

Zo oordeelde het hof Den Haag dat de GI een eerdere opdracht van de kinderrechter om thuisplaatsing te onderzoeken ten onrechte niet heeft uitgevoerd omdat de GI al een opvoedbesluit heeft genomen. ${ }^{44}$ Het hof overweegt daarom dat onderzoek naar de opvoedingsvaardigheden alsnog moet plaatsvinden en dat daartoe ook de omgang uitgebreid moet worden.

Ook de rechtbank Amsterdam was in het kader van een verlengingsverzoek van de uithuisplaatsing, anders dan de GI, van mening dat de aanvaardbare termijn nog niet was verstreken. ${ }^{45}$ De GI had al een besluit genomen over het perspectief van de kinderen, maar de rechtbank meende dat moeder nog geen eerlijke kans heeft gekregen en wijst erop dat een beslissing over het gezag niet door de GI maar door de rechtbank wordt genomen. Moeder moet alsnog, hangende een raadsonderzoek, een eerlijke kans worden geboden en daarvoor is het nodig dat de GI de omgangsmomenten tussen moeder en kin- deren uitbreidt. De uithuisplaatsing werd door de rechtbank voor korte tijd verlengd.

Uit een recente uitspraak van het gerechtshof Den Haag oordeelde het hof eveneens dat het perspectiefbesluit te voorbarig is. ${ }^{46}$ Hoewel de GI zich op het standpunt stelt dat de aanvaardbare termijn tussen de zes en twaalf maanden is, merkt het hof op dat de zes maanden nog niet waren verstreken bij de mededeling over het perspectief door de GI. Bovendien moet er volgens het hof ruimte zijn voor maatwerk. Het hof verwijst naar de parlementaire geschiedenis en geeft aan dat het ijkpunt hierbij is de periode van onzekerheid over het opgroeiperspectief die het kind kan overbruggen zonder vergaande ernstige schade op te lopen in zijn ontwikkeling. $\mathrm{Nu}$ het hier nog zeer jonge minderjarigen betreft, is het de vraag in hoeverre zij zich bewust zijn van deze onzekerheid. Het hof is van mening dat van de GI verwacht wordt dat alle mogelijke hulpverlening wordt ingezet voordat een dergelijk opvoedbesluit kan worden genomen.

Genoemde uitspraken sluiten ook aan bij de uitspraak van de Hoge Raad waarin werd overwogen dat artikel 8 EVRM eist dat bij kinderbeschermingsmaatregelen de belangen van het kind en die van de ouders tegen elkaar moeten worden afgewogen. Daarbij mag niet alleen naar het tijdsverloop van verblijf van het kind elders worden gekeken, maar moet ook de mogelijkheid van hereniging met de ouder serieus in overweging worden genomen. ${ }^{47}$ Ook Laterveer ${ }^{48}$ heeft in het Tijdschrift voor Familieen Jeugdrecht aandacht gevraagd voor het perspectiefbesluit. Hij is van mening dat het perspectiefbesluit vooruitloopt op een beslissing die de kinderrechter zou moeten nemen (namelijk wel of geen gezagsbeëindigende maatregel) en pleit voor het formaliseren van dit besluit. Volgens Laterveer zou in de wet kunnen worden vastgelegd dat de GI verplicht is de opvoedbeslissing ter toetsing/bekrachtiging voor te leggen aan de kinderrechter. Tevens pleit hij ervoor dit de status van een besluit in de zin van de Awb (art. 1:3) toe te kennen, zodat geborgd wordt dat dergelijke opvoedbeslissingen moeten voldoen aan de algemene beginselen van behoorlijk bestuur.

De Raad voor Strafrechtstoepassing en Jeugdbescherming (RSJ) heeft in december 2020 naar aanleiding van geuite zorgen door kinderrechters over de rechtspositie van ouders en kind bij een dergelijk opvoedbesluit advies uitgebracht. ${ }^{49}$ In dit advies doet de RSJ een drietal aanbevelingen: 1) realiseer een rechtspositieregeling voor ouders en kind; 2) leg wettelijk vast dat het perspectiefbesluit binnen drie maanden ter toetsing wordt voorgelegd aan de kinderrechter; en 3 ) voorzie het perspectiefbesluit van een motivering, waarbij de belangen van ouders en kind zorgvuldig zijn afgewogen. Waar-
41. Rb. Amsterdam 14 april 2020, ECLI:NL:RBAMS:2020:2345.

42. Rb. Noord-Nederland 13 mei 2020, ECLI:NL:RBNNE:2020:1905.

43. Gerechtshof Arnhem-Leeuwarden 26 mei 2020, ECLI:NL:GHARL: 2020:4000.

44. Gerechtshof Den Haag 3 juni 2020, ECLI:NL:GHDHA:2020:1000.

45. Rb. Amsterdam 25 mei 2020, ECLI:NL:RBAMS:2020:2759.
46. Hof Den Haag 24 februari 2021, ECLI:NL:GHDHA:2021:282.

47. HR 22 januari 2021, ECLI:NL:HR:2021:108. Zie ook: JPF 2021/53 met annotatie van J.H. de Graaf.

48. B. Laterveer, 'De opvoedbeslissing', FJR 2020/41, p. 185-189.

49. Het perspectiefbesluit in de jeugdbescherming, Raad voor Strafrechtstoepassing en Jeugdbescherming, 18 december 2020. 
borg in de procedure het recht van de ouders en het kind om gehoord te worden.

Minister Dekker heeft op 25 maart 2021 een beleidsreactie geformuleerd naar aanleiding van voornoemd RSJadvies. ${ }^{50}$ Hoewel de minister onderschrijft dat belangrijke beslissingen in de jeugdbescherming, zoals het perspectiefbesluit, moeten (kunnen) worden getoetst door de kinderrechter, ziet hij geen meerwaarde in het realiseren van een zelfstandige rechtspositieregeling voor het perspectiefbesluit. Dit zou volgens de minister een onnodige juridisering betekenen. De redenering hierbij is dat het uitgangspunt is dat als een GI meent dat het opvoedperspectief niet meer bij ouders ligt, de GI een verzoek bij de Raad moet indienen voor onderzoek naar een gezagsbeëindigende maatregel. Vervolgens kan de Raad een verzoek indienen bij de kinderrechter voor beëindiging van het gezag. In dat geval vindt een toets plaats door de kinderrechter en dit kan ook in hoger beroep nog worden getoetst door het gerechtshof. De minister onderschrijft daarnaast het belang van een spoediger proces dan nu het geval is; als een perspectiefbesluit wordt genomen, dan moet ook zo spoedig mogelijk een verzoek bij de Raad en eventueel bij de kinderrechter volgen. Ook onderschrijft de minister een zorgvuldige motivering van het besluit en het belang om ouders en kinderen te betrekken bij het besluit. In afwachting van de eindevaluatie van de herziene kinderbeschermingswetgeving ziet de minister mogelijkheden om het proces binnen het bestaande juridische kader te verbeteren en heeft hij aangekondigd de Kamer bij voortgangsbrief in november 2021 nader te informeren.

Wij kunnen het standpunt van de minister volgen als het gaat om het voorkomen van onnodige juridisering. Maar wij zien in de praktijk tegelijkertijd dat, los van de lange doorlooptijd van het proces voor een gezagsbeëindigende maatregel (inclusief de mogelijkheid van hoger beroep), maatwerk nodig is om ouders en minderjarigen tijdig een rechtsingang te bieden. Bovendien is niet in alle situaties een gezagsbeëindiging wenselijk (en op grond rechtspraak haalbaar) terwijl het perspectief wat de GI betreft helder is. In dergelijke gevallen is het in het belang van ouders en minderjarigen dat een rechterlijke toets mogelijk is.

\section{Machtiging uithuisplaatsing en reikwijdte}

Dat uithuisplaatsing van een minderjarige in het kader van een OTS uitsluitend toegestaan is met een (door de rechter verleende) machtiging tot uithuisplaatsing, is sinds 2015 in artikel 1:265a BW opgenomen. Dat dit - meer dan zes jaar na dato - in de praktijk toch nog voor onduidelijkheid zorgt illustreren de volgende twee uitspraken van het hof Arnhem-Leeuwarden. ${ }^{51}$

In de uitspraak van 18 februari 2021 merkt het hof op dat instemming van de moeder met een (gedeeltelijke) uithuisplaatsing van de minderjarige bij oma geen grond

50. Kamerbrief met beleidsreactie op het RSJ-advies over perspectiefbesluit in de jeugdbescherming, 25 maart 2021.

51. Gerechtshof Arnhem-Leeuwarden 18 februari 2021, ECLI:NL:GHARL: 2021:1606 en gerechtshof Arnhem-Leeuwarden 23 februari 2021, ECLI:NL:GHARL:2021:1736. kan vormen tot beëindiging van de machtiging uithuisplaatsing, nu de minderjarige onder toezicht is gesteld van de GI en uithuisplaatsing tijdens een ondertoezichtstelling alleen mogelijk is met een machtiging tot uithuisplaatsing. De uitspraak van 23 februari 2021 bevat een vergelijkbare overweging: de wet en de wetsgeschiedenis bieden geen ruimte voor vrijwillige uithuisplaatsing van een onder toezicht gestelde minderjarige.

Al eerder merkten wij op dat het vereiste van een machtiging uithuisplaatsing in OTS-zaken een opvallende keuze van de wetgever is in het licht van de Jeugdwet die op hetzelfde moment in werking trad en waarbij juist de nadruk is gelegd op de eigen kracht en verantwoordelijkheid van de ouder voor de opvoeding en verzorging. Als alle de neuzen dezelfde kant op staan en de ouders er achter kunnen staan om een kind elders te laten verblijven, kan de noodzaak om binnen de OTS een machtiging uithuisplaatsing te verzoeken ook wel eens als onnodig bureaucratisch of als een signaal van wantrouwen worden ervaren. In een uitspraak van de rechtbank Amsterdam van 28 november 2019 verblijven de kinderen bij hun oma en wordt een machtiging uithuisplaatsing afgegeven voor het geval de situatie daar onhoudbaar wordt. In die situatie accepteert de kinderrechter dat de kinderen zonder een machtiging bij hun oma verblijven. ${ }^{52}$

Ten aanzien van uithuisplaatsing, specifiek over de vraag wie toestemming moet geven als het pleeggezin met het pleegkind op vakantie wil, is recent door de Hoge Raad antwoord gegeven in het kader van een prejudiciële procedure. ${ }^{53}$

De Hoge Raad antwoordde op de vraag of pleegouders toestemming nodig hebben van de ouders met gezag of de GI voor een uitstapje of vakantie met de minderjarige dat het nemen van beslissingen over uitstapjes en vakanties met de minderjarige in beginsel tot de taken van de pleegouders behoort. Hiervoor is geen toestemming nodig van de met het gezag belaste ouders. Echter, in het kader van de taak van de GI bij de ondertoezichtstelling/uithuisplaatsing moet de GI er ook voor zorgen dat een omgangsregeling tussen de ouders met gezag en de minderjarige wordt nageleefd. Om deze taken te kunnen uitoefenen, moet de GI kunnen ingrijpen als de omgangsregeling van het kind met de ouders met gezag wordt geraakt door een door de pleegouders voorgenomen uitstapje of vakantie. Daarom moeten de pleegouders een voorgenomen uitstapje of vakantie met het kind binnen of buiten Nederland aan de GI melden als de uitvoering van de omgangsregeling van het kind met de ouders met gezag daardoor wordt geraakt, zodat de GI hiervoor toestemming kan verlenen of weigeren.

Daarnaast is de Hoge Raad van mening dat een geschil over een voorgenomen uitstapje of vakantie verband houdt met de uitvoering van de ondertoezichtstelling en als zodanig aan de kinderrechter kan worden voorgelegd

52. Rb. Amsterdam 28 november 2019, ECLI:NL:RBAMS:2019:9820.

53. HR 21 mei 2021, ECLI:NL:HR:2021:748. 
in het kader van de geschillenregeling als bedoeld in artikel 1:262b BW.

De beantwoording van de vragen ziet op een situatie waarin een minderjarige onder toezicht is gesteld en uit huis is geplaatst in een pleeggezin. De Hoge Raad overweegt dat de antwoorden ook gelden voor andere vormen van uithuisplaatsing, zoals plaatsing bij gezinshuisouders of in een residentiële instelling.

\section{Vaststelling omgangsregeling}

De GI heeft sinds 1 januari 2015 ruimere bevoegdheden ten aanzien van de omgangsregeling en het ouderschapsplan. Waar vóór die datum enkel een verzoek mogelijk was tot wijziging van een door de rechter vastgestelde omgangsregeling, maakt artikel 1:265g BW het mogelijk om tevens vaststelling van een omgangsregeling en vaststelling of wijziging van een ouderschapsplan te verzoeken.

In december 2018 heeft de Hoge Raad prejudiciële vragen beantwoord over de reikwijdte van artikel 1:265f en 1:265g BW. ${ }^{54}$ De Hoge Raad oordeelde onder meer dat binnen het huidige kader artikel 1:265f BW - de schriftelijke aanwijzing waarbij contact tussen ouders met gezag en minderjarige kan worden beperkt in het kader van een uithuisplaatsing - niet kan worden ingezet in geval van hoofdverblijf bij een gezagsouder. Argument hiervoor is dat de wet inmiddels de ingang van artikel 1:265g BW kent, hetgeen een lex specialis is ten opzichte van de algemene regeling van de schriftelijke aanwijzing. De Hoge Raad stelt dat als sprake is van een OTS zonder uithuisplaatsing, de GI alleen via artikel 1:265g de kinderrechter kan verzoeken voor de duur van de ondertoezichtstelling een regeling vast te stellen. Over de gevolgen die deze uitspraak heeft gehad voor de praktijk van de jeugdbescherming is in december 2019 door het CCRA een expertmeeting georganiseerd, waarover begin dit jaar een verslag is gepubliceerd in dit tijdschrift. ${ }^{55}$

Zoals hieruit en ook uit het artikel van Heuvelhorst en Van der Leij naar voren komt, was duidelijk geworden na de uitspraak van de Hoge Raad dat de uitspraak vooral tot uitvoeringsproblemen leidde, specifiek in het geval snelle stopzetting of schorsing van een omgangsof zorgregeling noodzakelijk wordt geacht door de GI. ${ }^{56}$ In april 2019 werd door de rechtbank Den Haag in een voorkomend geval, waarin risico bestond op eerwraak, via een verzoek voorlopige voorziening met onmiddellijke ingang de omgang stopgezet op verzoek van de GI. ${ }^{57}$ De rechtbank Amsterdam oordeelde dat een dergelijke opschorting van de omgang ook mogelijk was zonder voorafgaand verhoor, als een acute verandering in de situatie maakt dat de uitvoering van het zorgregeling niet meer in het belang van het kind is. ${ }^{58}$

54. HR 14 december 2018, ECLI:NL:HR:2018:2321.

55. Samenvatting expertmeeting CCRA over HR 14 december 2018: omgang in het kader van een ondertoezichtstelling, TVJr 2021, nr. 1

56. Zie ook J.I. Heuvelhorst \& D. van der Leij, 'De impact van een uitspraak van de Hoge Raad op de praktijk van de GI', FJR 2020/30.

57. Rb. Den Haag 18 april 2019, ECLI:NL:RBDHA:2019:5060.

58. Rb. Amsterdam 21 februari 2020, ECLI:NL:RBAMS:2020:1564.
Inmiddels volgen ook andere rechtbanken de lijn van Amsterdam en passen zij artikel 800 lid 3 juncto 809 lid $3 \mathrm{Rv}$ analoog toe. ${ }^{59}$ Dit betekent dat als onverkorte naleving van een door de rechter vastgestelde omgangsof zorgregeling een onmiddellijk en ernstig gevaar oplevert voor de minderjarige, een dergelijke regeling zonder hoor en wederhoor tijdelijk kan worden stopgezet. Binnen veertien dagen vindt vervolgens een zitting plaats waar deze stopzetting wordt besproken.

\section{Ineffectieve OTS}

Een terugkerend dilemma bij de GI's, maar duidelijk ook in de rechtspraak is of een OTS verlengd moet worden als er weliswaar nog sprake is van een ontwikkelingsbedreiging, maar de ondertoezichtstelling geen soelaas biedt, dan wel juist contraproductief is. Vooral in complexe scheidingszaken lopen GI's tegen de beperkingen binnen het systeem aan en blijkt een OTS soms weinig of geen meerwaarde te hebben.

Waar het gerechtshof Arnhem-Leeuwarden ${ }^{60}$ en het gerechtshof Den Haag ${ }^{61}$ meenden dat effectiviteit en uitvoering van de OTS niet doorslaggevend is bij de vraag of aan de gronden van de OTS is voldaan, komen we ook uitspraken tegen waarin, ondanks de nog aanwezige ontwikkelingsbedreiging, het gebrek aan toegevoegde waarde van de maatregel aanleiding is om de OTS niet verlengen. ${ }^{62}$

Zo wees het hof Den Bosch naar het visiedocument Expertteam ouderverstoting en achtte het hof, nu ouders hun verantwoordelijk nog steeds niet namen, verlenging van de OTS in strijd met de belangen van de kinderen. ${ }^{63}$

Deze opsomming van ontwikkelingen in de rechtspraak over de herziene kinderbeschermingsmaatregelen roept bij ons de vraag op hoe jeugdprofessionals - die al onder grote (werk)druk staan - met deze complexiteit om kunnen gaan. Door de wetgever goedbedoelde uitbreiding van middelen (zoals hiervoor genoemd het verzoek vaststelling omgangsregeling) roepen nieuwe praktijkproblemen op omdat ze leiden tot voor jeugdprofessionals lastig te doorgronden rechtspraak. En voor veelvoorkomende en tamelijk overzichtelijke situaties - vakantie van een onder toezicht gesteld kind dat in een pleeggezin is geplaatst - zijn prejudiciële vragen nodig om helderheid te verschaffen over wat wanneer wel of niet is toegestaan. Dit terwijl er al door de verschillende stelsels heen kinderen met hun pleegouders op vakantie gaan.

59. Zoals de Rb. Gelderland in een uitspraak van 8 januari 2021 (niet gepubliceerd).

60. Gerechtshof Arnhem-Leeuwarden 16 februari 2018, ECLI:NL:GHARL: 2018:1331.

61. Gerechtshof Den Haag 1 september 2020, ECLI:NL:GHDHA: 2020:1727.

62. Rb. Zeeland-West-Brabant 11 augustus 2020 (pub. 20 augustus 2020), ECLI:NL:RBZWB:2020:3887; gerechtshof 's-Hertogenbosch 11 juni 2020, ECLI:NL:GHSHE:2020:1770 (JPF 2020/119); hof Den Bosch 18 maart 2021, ECLI:NL:GHSHE:2021:778.

63. Zie ook mr. S.C.G.A. Duivenvoorde, 'Kinderbeschermingsmaatregelen in conflictscheidingen: in het belang van het kind?' FJR 2021/27. 


\section{De Jeugdwet}

Onder het kopje 'Actuele ontwikkelingen stelselbreed' hebben we stilgestaan bij de knelpunten die worden ervaren in de jeugdhulp en jeugdbescherming. In deze paragraaf zullen we nog inzoomen op een antal specifieke onderwerpen die betrekking hebben op de uitvoering van de Jeugdwet: drangtrajecten, het Besluit jeugdhulp, woonplaatsbeginsel, informatieplicht jegens de GI, pettenvraagstuk en tuchtrecht.

\section{Drangtrajecten}

In 2017 schreven wij over de ontwikkeling - na de transitie in 2015 - dat GI's naast het uitvoeren van hun wettelijke taken, hun expertise ook in het vrijwillig kader aanboden aan gemeenten in de vorm van zogenaamde 'drangtrajecten'. In de loop van de tijd zijn ook gemeenten zelf invulling gaan geven aan deze vorm van vrijwillige, maar niet-vrijblijvende, vorm van begeleiding, meestal ter voorkoming van een kinderbeschermingsmaatregel. Zowel uit de evaluatie van de Jeugdwet als van de Wet Herziening kinderbeschermingsmaatregelen kwam naar voren dat deze niet wettelijk geregelde vorm van begeleiding de nodige vragen opriep. Betrokkenen kunnen drang ervaren als 'dwang', zonder over de vereiste wettelijke rechtswaarborgen te beschikken. Op basis van de deelstudie juridisch van de Eerste Evaluatie Jeugdwet wordt geconcludeerd: De uitvoering van 'drang'-trajecten in het schemergebied tussen vrijwilligheid en dwang (jeugdbescherming) door de jeugdbeschermingsorganisaties leidt tot rolonduidelijkheid en is onwenselijk'.

Als vervolgens ook advocaten, rechtswetenschappers en de Kinderombudsman hun zorgen uiten over de rechtspositie van jeugdigen en ouders bij de inzet van drang, is dit aanleiding voor de RVS en de RSJ om hierover advies uit te brengen. ${ }^{64}$ In hun rapport, 'intensieve vrijwillige hulp' genaamd, doen zij aanbevelingen om een juridisch gerechtvaardigde en ethisch verantwoorde jeugdzorgpraktijk te realiseren. Zij stellen voor om voortaan de term 'intensieve vrijwillige hulp' te gebruiken, hetgeen inhoudt: 'een proces van hulp en zorg verlenen in het vrijwillige kader van de jeugdzorg, waarbij de jeugdprofessional gradueel meer invloed uitoefent, meer verantwoordelijkheid neemt en daarmee steeds intensiever hulp en zorg verleent én tegelijkertijd de vrijmilligheid van de hulp garandeert.' Bovendien moet volgens beide organisaties in het jeugdzorgstelsel specialistische kennis en kunde voor het verlenen van intensieve vrijwillige hulp in het vrijwillig kader worden opgebouwd en beschikbaar zijn. Professionals moeten in elke situatie opnieuw verschillende rechten, plichten en waarden en normen afwegen.

Wat ons betreft hebben kinderen en gezinnen vanzelfsprekend recht op duidelijkheid over hun rechtspositie en rechtsbescherming en zullen professionals dit ook

64. Intensieve vrijwillige hulp, 'Heldere grenzen aan drang in de jeugdzorg', RSJ \& RVS, 25 november 2019. onderschrijven. Tegelijkertijd ligt de opdracht in de Jeugdwet om zoveel mogelijk samen met gezinnen problemen op te lossen en kinderbeschermingsmaatregelen te voorkomen. Dit vraagt om het zoeken naar een balans tussen enerzijds het in beweging krijgen van ouders en kinderen en anderzijds een passende rechtsbescherming bieden omdat het al snel gevoeld kan worden als drang om mee te werken om een kinderbeschermingsmaatregel te voorkomen. Dit vraagt van de professionals dat zij, conform de Richtlijn gezamenlijk beslissen, ouders en kinderen meenemen in hun overwegingen en gezamenlijk beslissen over de inzet van hulp.

\section{Het besluit jeugdhulp}

In een uitspraak van 1 mei 2019 heeft de Centrale Raad van Beroep duidelijkheid gegeven over wat van gemeenten wordt verwacht als het gaat om het onderzoek of aanspraak bestaat op een individuele voorziening jeugdhulp op grond van artikel 2.3 Jeugdwet. Het college dient de volgende stappen te doorlopen:

1. De gemeente moet eerst vaststellen wat de hulpvraag van de jeugdige of de ouders is.

2. Hierna moeten de opgroei- en opvoedingsproblemen of psychische problematiek in kaart worden gebracht.

3. Vervolgens moet worden vastgesteld welke problemen en stoornissen er zijn en bepaalt de gemeente welke hulp nodig is.

4. Ten slotte gaat de gemeente na of die hulp bijvoorbeeld door de ouders kan worden geboden.

5. Indien nodig moet de gemeente zich bij de besluitvorming laten adviseren door een specifieke (jeugdhulp)deskundige. ${ }^{65}$

Van het college mag verwacht worden dat het actief onderzoekt wat de hulpvraag is en dat voldoende inzichtelijk wordt gemaakt op basis waarvan de aard en omvang van de benodigde jeugdhulp is bepaald. ${ }^{66}$ Van de (ouders van de) jeugdige mag worden verwacht dat hij (deze) medewerking verleent om de benodigde informatie te verstrekken, zodat het college tot een zorgvuldige afweging kan komen van een aanvraag om jeugdhulp. ${ }^{67}$

In de Jeugdwet is niet - zoals in de Wmo 2015 - nader omschreven hoe de aanvraagprocedure om een individuele voorziening jeugdhulp moet zijn ingericht. Veel gemeenten hebben de keuze gemaakt om hierbij aan te sluiten bij de procedure voor een maatwerkvoorziening zoals die in de Wmo 2015 is bepaald (melding onderzoek - aanvraag maatwerkvoorziening). Deze procedure wijkt af van de anvraagprocedure van de Algemene wet bestuursrecht (hierna: Awb). In een uitspraak van 18 maart 2020 oordeelde de rechtbank Rotterdam dat voor zover wordt verzocht om jeugdhulp artikel 2.5 lid 1 van de Verordening van de gemeente

65. CRvB 1 mei 2019, ECLI:NL:CRVB:2017:1477

66. Zie o.a. Rb. Oost-Brabant 8 januari 2021, ECLI:NL:RBOBR:2021:53; Rb. Noord-Holland 12 augustus 2020, ECLI:NL:RBNHO:2020:3025; rechtbank Noord Nederland, 4 september 2020, ECLI:NL:RBNNE:2020:3025

67. CRvB 3 februari 2021, ECLI:NL:CRVB:2021:410. 
Rotterdam wegens strijd met de Awb verbindende kracht mist en deze bepaling in het geval van eiser buiten toepassing moet worden gelaten. Vervolgens gaat de rechtbank in welk moment als 'aanvraag' moet worden beschouwd en dat conform de Awb de gemeente hierop uiterlijk binnen acht weken een besluit had moeten nemen. ${ }^{68}$ Voor gemeenten is het dus bij de uitvoering van de Jeugdwet van belang om goed scherp te blijven op de Awb-beslistermijn.

\section{Woonplaatsbeginsel}

In ons artikel uit 2017 makten wij melding van de onduidelijkheid en de onwenselijke uitkomsten waar het woonplaatsbeginsel uit artikel 1.1 van de Jeugdwet toe leidde.

De huidige definitie is dat die gemeente verantwoordelijk is waar de feitelijke woonplaats van de ouder met gezag ligt. Uit de uitvoeringstoets Woonplaatsbeginsel werd duidelijk wat de knelpunten zijn bij de toepassing van het woonplaatsbeginsel. ${ }^{69}$ In veel gevallen volgt het gezag niet uit de Basisregistratie Personen (BRP) en moet het gezagsregister geraadpleegd worden en is ook voor de ouders niet altijd duidelijk wie het gezag heeft. Het vaststellen van wie het gezag over een minderjarige heeft is dus niet altijd eenvoudig. Daarnaast zijn er in de praktijk geschillen over de feitelijke woonplaats van de ouder met gezag, bijvoorbeeld in geval van scheiding/co-ouderschap als ouders met gezag in andere gemeenten wonen. Ook levert het huidige woonplaatsbeginsel verkeerde prikkels op omdat bij voogdij, waar de ouders met gezag niet meer in beeld zijn, de woonplaats leidend is waar het kind (toevallig) uit huis is geplaatst en niet meer de gemeente van herkomst. Een en ander heeft geleid tot een wetsvoorstel strekkende tot wijziging van het woonplaatsbeginsel. Op 28 januari 2020 is door de Tweede Kamer al ingestemd met deze wijziging en aanvankelijk was inwerkingtreding per 1 januari 2021 voorzien. Dit is - vanwege de coronacrisis en herijking van het gemeentefonds - uitgesteld naar 1 januari 2022. In het 'nieuwe' woonplaatsbeginsel zal primair worden aangesloten bij de BRP-registratie van de jeugdige, met uitzondering van jeugdigen met verblijf. Daarvoor wordt verantwoordelijk de gemeente waar de jeugdige vandaan komt. Deze oplossing laat de prikkel bij de gemeente waar het kind vandaan komt en sluit aan bij de uitgangspunten van de Jeugdwet.

\section{Informatieplicht jegens de GI}

In ons vorige artikel hebben wij gewezen op een uitspraak waarin werd uitgemaakt dat het zogenaamde medische blokkeringsrecht dient te worden gepasseerd als medische informatie noodzakelijk is voor een goede uitvoering van de ondertoezichtstelling. ${ }^{70} \mathrm{Wij}$ merken dat in de praktijk nog niet alle professionals bekend zijn met de informatieplicht aan de GI bij een OTS. Daarom willen wij nog graag wijzen op een uitspraak van

68. ECLI:NL:RBROT:2020:2333.

69. Uitvoeringstoets woonplaatsbeginsel Jeugdwet, JB Lorenz, mei 2017.

70. Rb. Den Haag 19 september 2016, ECLI:NL:RBDHA:2016:11303.
4 december 2020 van de rechtbank Gelderland waarin de rechtbank overweegt dat de GI voor een goede beoordeling van de mogelijkheden om de zorgregeling te herstarten informatie nodig heeft van de vader en zijn behandelaars over de diagnose die bij de vader is gesteld, de ingezette behandeling, de duur van de behandeling en de prognose. De rechtbank merkt op dat de behandelaren, ook zonder toestemming van de vader en met doorbreking van hun medisch beroepsgeheim, op grond van artikel 7.3.11 lid 4 Jeugdwet gehouden zijn de GI alle informatie te verstrekken die voor de GI noodzakelijk is om de ondertoezichtstelling uit te voeren en meer specifiek te kunnen beoordelen of en zo ja op welke manier omgang tussen de minderjarige en de vader mogelijk is. ${ }^{71}$

Ook in een tuchtbeslissing van het college van toezicht SKJ is overwogen dat de jeugdprofessional geen toestemming nodig heeft gehad om de behandelend arts van de zoon te benaderen. Op grond van artikel 7.3.11 lid 4 Jeugdwet is ook geen toestemming nodig (geweest) om de school van de kinderen te benaderen, aldus het college. $^{72}$

\section{Pettenvraagstuk}

In ons vorige artikel is ook al de orde geweest dat er voor professionals die werken in de lokale toegang van de gemeente veelal onduidelijkheid bestaat over de eigen taak: is het sociaal wijkteam nu indicatiesteller of ook jeugdhulp aan het verlenen? De onduidelijkheid hierover leidt tot onduidelijkheid over wie welke persoonsgegevens mag verwerken. Binnen het programma sociaal domein is daarom voor gemeenten een handreiking 'Wijkteams en het pettenvraagstuk: als hulp en toeleiding samenkomen' ontwikkeld. De handreiking zet uiteen dat er voor verschillende rollen verschillende regels gelden als het gaat om het verwerken van persoonsgegevens. En dat het daarom van belang is dat de gemeente en de bij het wijkteam betrokken organisaties hierover afspraken met elkaar maken. ${ }^{73}$ De handreiking maakt inzichtelijk dat de wet- en regelgeving het voor gemeenten niet eenvoudig maakt om tot een meer integrale aanpak en werkwijze te komen.

\section{Tuchtrecht}

Ook het SKJ tuchtrecht is geëvalueerd. Op 20 november 2020 is het rapport 'Evaluatie 5 jaar tuchtrecht in de jeugdzorg' gepubliceerd. ${ }^{74}$ Geconcludeerd wordt onder meer het volgende:

- De tuchtprocedure is een zorgvuldige tuchtprocedure die klantvriendelijk en professioneel is vormgegeven. De inrichting van een voorportaal heeft ertoe geleid dat het grootste deel van de tuchtklachten niet inhoudelijk wordt behandeld, vooral omdat deze niet-ontvankelijk worden verklaard.

71. ECLI:NL:RBGEL:2020:7164.

72. SKJ 18 januari 2021, 19.582Tb

73. VNG, 'Wijkteams en het pettenvraagstuk: als hulp en toeleiding samenkomen', november 2020.

74. L. Schackmann, V.D.V. Sankatsing, R. de Boer, M. Bruning \& R.D. Friele, Evaluatie 5 jaar tuchtrecht in de jeugdzorg, Utrecht: Nivel, 2020. 
- Het leereffect van het tuchtrecht is (nog) niet optimaal. Niet in alle beslissingen van het tuchtcollege is duidelijk wat het beoordelingskader is en hoe het handelen van de professional waarover wordt geklaagd op basis daarvan wordt beoordeeld, terwijl dit wel van belang is voor consistente en voorspelbare tuchtrechtspraak.

- Als niet-beoogde, niet gewenste effecten worden genoemd dat vooral ouders die zich in een complexe scheidingssituatie bevinden - vooral in de niet-vrijwillige jeugdzorg - het tuchtrecht gebruiken om hun gelijk te halen, als een vorm van klachtrecht en hiervoor soms alle klachtmogelijkheden aanwenden. Dit kan komen doordat het onduidelijk is voor de cliënt waar ze een klacht het beste kunnen indienen, doordat ze het verschil tussen beide procedures niet zien, doordat er sprake is van een grijs gebied tussen het beleid van een organisatie en het handelen van een professional of doordat deze ouders alles in het werk willen stellen om bepaalde beslissingen terug te draaien.

- Voor specifiek jeugdbeschermers kan de vraag worden gesteld of de kern van de taak van een jeugdbeschermer, dat wil zeggen het verminderen of opheffen van de ernstige ontwikkelingsbedreiging van de kinderen die onder zijn verantwoordelijkheid vallen, wel voldoende door de tuchtrechter wordt getoetst, nu het vooral klachten van ouders betreft die de bemoeienis van deze professional met hun kinderen niet willen.

- Structurele klagers worden door professionals in de jeugdzorg als belastend ervaren. Het kost professionals veel tijd om zich voor te bereiden en deel te nemen aan hoorzittingen van een klachtencommissie. Ook is het emotioneel belastend (vooral als het tevens om tuchtrecht gaat). ${ }^{75}$

Aanbevolen wordt het stroomlijnen en waar mogelijk harmoniseren van de klachtenregelingen. Er wordt in overweging gegeven om voor klachten die voortkomen uit het gedwongen kader te zoeken naar een getrapt systeem van het indienen van een tuchtklacht. Als dan blijkt dat de klacht het professionele handelen betreft, dan zou de klacht alsnog - door de klachtencommissie of ombudsman - aan de tuchtrechter voorgelegd kunnen worden. Ten aanzien de aard van de klagers: nagegaan zou moeten worden of het mogelijk is om andere klagers, zoals professionals of institutionele klagers, een groter aandeel te laten krijgen in het aantal ingediende tuchtklachten, aldus de onderzoekers. ${ }^{76}$

Het klacht- en tuchtrecht en stapeling van procedures houden de gemoederen bezig. $Z_{o}$ is er een tweetal moties ingediend waarin de regering wordt verzocht om te onderzoeken hoe de verschillende procedures met betrekking tot klachtbemiddeling en/of geschilbeslechting bij elkaar te voegen en te stroomlijnen met als doel

75. Zie ook het onderzoek 'Lastig klaaggedrag bij Gecertificeerde instellingen' van Van Montfoort, gepubliceerd op 16 oktober 2020.

76. Zie ook R. de Boer \& M. Bruning, 'Vijf jaar tuchtrecht in de jeugdzorg; aandachtspunten voor de toekomst', FJR 2021/36 zorgprofessionals zoveel mogelijk te ontlasten om in overleg te treden met belangenorganisaties, onderzoekers en ervaringsdeskundigen om tot komen tot sterke vereenvoudiging van klacht- en beroepsprocedures.

Wij hopen van harte dat hierin stappen gezet zullen worden, omdat met name een stapeling van procedures belastend is voor de professionals en cliënten - met name ook jongeren - niet goed op de hoogte zijn van hun rechtsbescherming. Daarbij is het zoeken naar een goed evenwicht tussen het bieden van toegankelijke rechtsbescherming, maar die mag er niet toe leiden dat een professional te veel wordt belemmerd in het uitvoeren van zijn kerntaak richting het betrokken kind.

\section{Conclusie}

$\mathrm{Na}$ zes jaar Jeugdwet en Herziene Kinderbeschermingsmaatregelen zou de transformatie toch langzamerhand haar beslag hebben moeten gekregen. Het tegendeel blijkt het geval. De inrichting van de jeugdzorg blijft piepen en kraken. Iedereen is verstrikt geraakt in een stelsel van grote financiële tekorten, wachttijden, een tekort aan gekwalificeerde professionals, een lange keten en een grote diversiteit aan wet- en regelgeving. Nederland is na zes jaar Jeugdwet en herziening van de kinderbeschermingsmaatregelen toe aan een nieuwe, andere inrichting van de zorg aan kinderen en gezinnen. Is het Toekomstscenario voor kind- en gezinsbescherming waar wij in het eerste deel aandacht aan hebben besteed, hierop het antwoord? De vier pijlers waarop het scenario is gestoeld: gezinsgericht rechtsbeschermend en transparant - eenvoudig lerend, spreken ons aan. Hiervoor hebben we kunnen zien dat we de jeugdhulp en jeugdbescherming complex hebben gemaakt, ook qua wet- en regelgeving, en dat rechterlijke uitspraken nodig zijn om hierover uitleg te geven. De neiging bestaat om als iets niet goed werkt met nieuwe regels en protocollen te komen. Maar soms geldt: less is more en dus niet voor iedere organisaties eigen regels over bijvoorbeeld klachten, maar één uniforme rechtsbescherming. Dat maakt het voor zowel kinderen, jongeren en ouders overzichtelijk en daarmee hopelijk ook beter toegankelijk voor degenen die niet zo snel de juridische wegen weten te bewandelen, zoals jongeren. Mogelijk kan vereenvoudiging of vermindering van regels tevens een groep kritische ouders juist wat begrenzen in het bewandelen van de juridische wegen. En het kan hopelijk ook bijdragen aan een lagere belasting voor professionals, met name voor jeugdbeschermers, zodat zij de kostbare tijd en energie kunnen besteden aan tijd en aandacht voor de betrokken kinderen en om samen met het gezin aan de slag te gaan om de situatie van het gezin te verbeteren.

De maatschappelijke opdracht lijkt simpel en overzichtelijk: organiseer met elkaar een stelsel waarin kinderen, jongeren, ouders en anderen zich gehoord en gezien voelen, waarin professionals de ruimte en tijd hebben om samen met het gezin dat te doen wat nodig is met 
een gezinsgerichte blik met ruimte voor doorontwikkelingen en reflectie. De doelstellingen van de Jeugdwet zijn zo gek nog niet. En toch lukt het maar niet goed om hier te komen. Vele onderzoeken en analyses zijn er al gemaakt over de vraag waarom het maar niet lukt. En het gekke, of misschien ook het mooie, is dat de bevindingen in hedendaagse analyses niet zoveel verschillen van die van jaren geleden. Er lijkt dan niets anders op te zitten dan het nu eens echt over een hele andere boeg te gooien. En dat zal van iedereen iets vragen. Laten we - zoals in het Toekomstscenario ook wordt voorgesteld - vooral de tijd nemen om te komen tot het 'hoe', met tijd voor stilstand en reflectie: doen we nog het goede? Van belang is volgens ons ook om ontwikkelingen c.q. veranderingen in gang te zetten die passen bij de behoefte en het gedrag van de hedendaagse mens. En oog te hebben voor maatschappelijke ontwikkelingen zoals de complexe scheidingen van ouders met een goede opleiding en kritische blik die een substantieel deel van de cliënten zijn gaan vormen - het geloof in maakbaarheid - individualisering - gelijkheidsprincipe en incidentenvrees. ${ }^{77}$ Deze ontwikkelingen en behoeften kunnen in de tijd veranderen en vragen daarom om flexibiliteit van het stelsel en ruimte voor maatschappelijk debat over moreel-ethische vraagstukken die dit oproept.

Wordt vervolgd! 